UDC 661.185

\title{
PROPOXYLATION OF ALIPHATIC AMINES BY PROPYLENE OXIDE
}

\author{
Z.H.Asadov, I.A.Zarbaliyeva, S.H.Zargarova \\ Acad. Y.H.Mamedaliyev Institute of Petrochemical Processes \\ Baku,30 Khojalyavenue, e-mail: anipc@dcacs.ab.az
}

\begin{abstract}
Nonyl amine, octadecyl amine and aminoamide of carboxylic acid fraction of linseed oil have been propoxylated using propylene oxide and the structure and composition of obtained propoxylates confirmed by IR-spectroscopy. Tensiometric measurements made it possible to reveal high surface activity of these propoxylates. As a result of laboratory tests through the use of thin films of Ramana crude oil on the surface of distilled, fresh and sea water, a good petroleum-collecting capacity of the synthesized reagents has been determined.
\end{abstract}

Keywords: amines, propoxylation, surface activity, petroleum-collecting properties

\section{INTRODUCTION}

Surfactants are widely used in various spheres of mankind's activity [1]. Among these spheres, oil and gas industry must be mentioned first of all [2, 3]. In the world practice, mainly ethoxylates of higher alcohols and monocarboxylic acids are utilized [4]. However, over the past two decades, propoxylates of the mentioned alcohols and acids also drew great interest of specialists [2, $5,6]$.

\section{EXPERIMENTAL}

Nonyl amine and octadecyl amine were products of "Alfa Aesar" firm (Great Britain).

Linseed oil was the product of "Sultanbeyli" firm (Istanbul, Turkey).

Propylene oxide (PO) was the industrial product of "Organic Synthesis" plant (Sumgayit, Azerbaijan) of $99.8 \%$ purity.

Sodium hydroxide was used as a reagent of "analytically pure" grade ("Chemapol" firm, Czech Republic).

Potassium hydroxide was taken as a reagent of "analytically pure" grade ("Chemapol" firm, Czech Republic).

Nonyl amine and octadecyl amine were propoxylated by $\mathrm{PO}$ at $53^{\circ} \mathrm{C}$ and equimolar ratio of reactants for six hours in an autoclave made of stainless steel and equipped with a controlled heating system. The unreacted
The present paper highlights propoxylation of higher aliphatic amines. An introduction of propoxy-groups into composition of alkyl amines promises obtaining of valuable surface-active compounds. A study into their physicalchemical properties is also of interest, especially for identifying new fields of application of these surfactants.

amount of PO was evaporated from the final mixture at mild temperature until a constant mass obtained. By gravimetric measurements conversion of $\mathrm{PO}$ and average degree of propoxylation $-\mathrm{n}$ (the number of PO moles added to $1 \mathrm{~mol}$ of amine) were calculated. In both cases, the value of " $n$ " was close to 1.0.

Propoxylated nonyl amine is a white paraffin-like soft solid. Propoxylated octadecyl amine is also a white paraffinic solid.

Diethylene triamine (DETA) was the reagent of Russia, molar mass-73.14 q. mol $^{-1}$, density-0.707 $\mathrm{qml}^{-1}$, boiling point-55-56 ${ }^{\circ} \mathrm{C}$, refractive index was $1.3850\left(20^{\circ} \mathrm{C}\right)$.

Surface activity of the synthesized products was studied at the air-water interface by means of "KSV Sigma 702" tensiometer (Israel) using Du Nouy ring [7]. The method 
consists in measuring the maximum force necessary for detaching the ring off the liquid surface.

Specific electro-conductivity $(\kappa)$ of the aqueous solutions of the obtained compounds was measured by "Anion-4120" electroconductometer (Russian Federation).

Petroleum-collecting capacity of the synthesized surfactants was evaluated according to the well-known method [3]. Distilled, fresh and sea waters were introduced into three Petri dishes ( $40 \mathrm{ml}$ per each dish). 1 $\mathrm{ml}$ of petroleum was added to the surface of water in each dish (thickness of petroleum layer makes up $\sim 0.165 \mathrm{~mm}$ ). The surfactant (or its 5\% wt. solution in water or ethanol) was added at the amount of $0.02 \mathrm{~g}$. The petroleumcollecting capacity was estimated according to a change of surface area of the petroleum which becomes collected into a spot. This area was measured by a stencil plate with accuracy $\sim 10 \%$. The petrocollecting activity was characterized by collecting ratio $-\mathrm{k}$, which indicates how many times the surface area of the initial oil slick decreases under impact of the surfactant. Retention time of the collected oil - $\tau$ is also registered and used for characteristics of the reagent.

Petrodispersing capacity of the reagents was estimated as the ratio of the cleaned water surface area and surface area of the initial oil slick (in \%).

Characteristics of the used fresh water: density at $20^{\circ} \mathrm{C} 0.996 \mathrm{~g} \cdot \mathrm{mL}^{-1} ; \mathrm{pH}$ 7.0-7.6; chemical composition (g-equiv / $100 \mathrm{~g}$ ): $\mathrm{Ca}^{2+}$ 0.0052; $\mathrm{Mg}^{2+}$ 0.0023: $\mathrm{Cl}^{-} 0.0007 ; \mathrm{SO}_{4}^{2-}$ $0.0044 ; \mathrm{HCO}_{3}^{-} 0.0273 ; \mathrm{CO}_{3}^{2-} 0.0009$; total

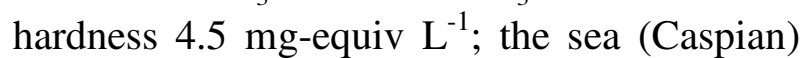
water: density at $20^{\circ} \mathrm{C} 1.0098 \mathrm{~g} \cdot \mathrm{mL}^{-1}$; $\mathrm{pH} 7.7$; chemical composition (mg / $1000 \mathrm{~g}): \mathrm{Na}^{+}$ 2650; $\mathrm{K}^{+} 20: \mathrm{Ca}^{2+} 250 ; \mathrm{Mg}^{+2} 900 ; \mathrm{NH}_{4}^{+} 0.15$; $\mathrm{Cl}^{-}$500; $\mathrm{SO}_{4}^{2-}$ 2800; $\mathrm{NO}_{3}^{-} 0.1 ; \mathrm{PO}_{4}^{3-} 0.35$; $\mathrm{SiO}_{2}$ 0.5; total hardness $69.0 \mathrm{mg}$-equiv. $\mathrm{L}^{-1}$.

Ramana crude oil had the following characteristics: at $20^{\circ} \mathrm{C}$ the density -0.86 $\mathrm{g} \bullet \mathrm{mL}^{-1}$; kinematic viscosity at $20^{\circ} \mathrm{C}-0.16 \mathrm{cSt}$.

\section{RESULTS AND THEIR DISCUSSION}

The performed reactions of PO with nonyl amine and octadecyl amine may be described by the following scheme:

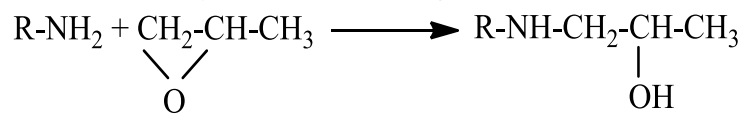

where $\mathrm{R}$ is $\mathrm{C}_{9} \mathrm{H}_{19}$ or $\mathrm{C}_{18} \mathrm{H}_{37}$.

The structure and composition of the obtained alkyl aminoalcohols were identified by İR-spectroscopy method. For example, in the spectrum of octadecyl isopropylolamine there are the following absorption bands $\left(\mathrm{cm}^{-}\right.$ $\left.{ }^{1}\right): 3329.9 \vee(\mathrm{OH}), 3274.8 \vee(\mathrm{NH}), 2957.0$, 2914.3 and $2849.0 \vee(\mathrm{CH}), 1643.6,1568.1$ and $848.9 \delta(\mathrm{N}-\mathrm{H}), 1467.7,1380.9$ and $1342.3 \delta$ $(\mathrm{CH}), 1307.2 \vee(\mathrm{C}-\mathrm{N}), 1157.6$ and $951.2 \vee(\mathrm{C}-$ $\mathrm{N}), 1043.6, v(\mathrm{C}-\mathrm{O}), 718.4, \delta\left(\mathrm{CH}_{2}\right)_{\mathrm{x}}$.

Results of tensiometric measurements of interfacial tension $(\sigma)$ at the border of aqueous solutions of the obtained alkyl aminoalcohols with air as well as the determined values of specific electro-conductance of these solutions are given in Table 1.

Table 1. Results of measurements of interfacial tension at the border of aqueous solutions of the synthesized alkyl aminoalcohols with air and specific electro-conductance

\begin{tabular}{|c|c|c|c|}
\hline $\begin{array}{c}\text { Concentration of aqueous } \\
\text { solution of alkyl aminoalcohol, } \\
\% \text { wt. }\end{array}$ & $\begin{array}{c}\text { Interfacial tension, } \\
\mathrm{mN} / \mathrm{m}\end{array}$ & $\begin{array}{c}\text { Specific electrocon- } \\
\text { ductance, } \mu \mathrm{S} / \mathrm{cm}\left(20^{\circ} \mathrm{C}\right)\end{array}$ & Remarks \\
\hline \multicolumn{2}{|c|}{ Nonyl isopropylolamine $\left(19^{\circ} \mathrm{C}\right)$} & $\begin{array}{l}\text { Amine number }-54.75 \\
\mathrm{mg} \mathrm{HCl} / \mathrm{g}\end{array}$ \\
\hline 0.010 & 38.97 & 16.3 & \\
\hline
\end{tabular}




\begin{tabular}{|c|c|c|c|}
\hline 0.025 & 28.56 & 32.9 & \multirow{19}{*}{$\begin{array}{c}\text { At the lack of surfactant } \\
\sigma \text { is } 72.0 \mathrm{mN} / \mathrm{m}\end{array}$} \\
\hline 0.050 & 31.50 & 51.5 & \\
\hline 0.100 & 26.51 & 94.5 & \\
\hline 0.300 & 25.46 & 134.7 & \\
\hline 0.500 & 23.95 & 220.8 & \\
\hline 1.000 & 24.34 & 302.0 & \\
\hline 3.000 & 23.93 & 208.6 & \\
\hline 5.000 & 24.13 & 229.0 & \\
\hline 7.000 & 24.51 & 171.4 & \\
\hline \multicolumn{3}{|c|}{ Octadecyl isopropylolamine $\left(21^{\circ} \mathrm{C}\right)$} & \\
\hline 0.01 & 34.69 & 11.6 & \\
\hline 0.03 & 33.90 & 8.5 & \\
\hline 0.05 & 33.16 & 8.1 & \\
\hline 0.10 & 32.87 & 24.7 & \\
\hline 0.30 & 32.54 & 18.7 & \\
\hline 0.50 & 32.98 & 23.1 & \\
\hline 1.00 & 33.16 & 11.3 & \\
\hline 3.00 & 33.88 & 50.8 & \\
\hline 5.00 & 34.51 & 19.7 & \\
\hline
\end{tabular}

As is seen from the obtained tensiometric results, nonyl iso-propylolamine is more surface-active than octadecyl isopropylolamine. The first alkyl aminoalcohol lowers $\sigma$ from 72.0 down to $24.1 \mathrm{mN} / \mathrm{m}$ (at concentration $5.0 \% \mathrm{wt}$.) whereas the second one decreases the interfacial tension down to only $32.5 \mathrm{mN} / \mathrm{m}$ (at concentration $0.3 \% \mathrm{wt}$.).

Electroconductometric analysis shows that aqueous solutions of nonyl<smiles>[R]NCC(C)O</smiles>

In Tables 2 and 3 , the results of laboratory studies of petrocollecting capacity of the synthesized surfactants are presented.

As is seen from Table 2, nonyl isopropylolamine in unthinned state is effective in all three waters $\left(\mathrm{k}_{\max }\right.$ is 44.25 in distilled and fresh waters, 22.25- in the sea water; $\tau$ exceeds 3 days in all three cases). $5 \%$ isopropylolamine have markedly higher values of specific electroconductivity than those of octadecyl isopropylolamine which may be explained by presence of significantly shorter alkyl group in the first one. Manifestation of conductivity by aqueous solutions of noncharged alkyl aminoalcohols is ensured by partial hydration of amino-fragments with the charged groups as follows:

Table 2. Results of laboratory studies of petrocollecting capacity of nonyl isopropylolamine with regard to Ramana crude oil thin (thickness $\sim 0.17 \mathrm{~mm}$ ) film; room conditions

\begin{tabular}{|c|l|l|l|l|l|l|}
\hline \multirow{2}{*}{ State of reagent } & \multicolumn{3}{|c|}{ Distilled water } & \multicolumn{2}{c|}{ Fresh water } & \multicolumn{2}{c|}{ Sea water } \\
\cline { 2 - 7 } & \multicolumn{1}{|c|}{$\tau$, hour } & $\mathrm{k}$ & $\tau$, hour & $\mathrm{K}$ & \multicolumn{1}{c|}{$\tau$, hour } & $\mathrm{k}$ \\
\hline & 0.17 & 10.66 & 0.17 & 11.05 & 0.17 & 10.66 \\
& 21.00 & 11.26 & 21.00 & 11.26 & 21.00 & 11.26 \\
Unthinned reagent & 25.50 & 14.92 & 25.50 & 14.92 & 25.50 & 11.26 \\
& 44.50 & 22.25 & 44.50 & 22.25 & 44.50 & 14.92 \\
& 68.00 & 44.25 & 68.00 & 44.25 & 68.00 & 22.25 \\
& 72.00 & 44.25 & 72.00 & 44.25 & 72.00 & 22.25 \\
\hline
\end{tabular}




\begin{tabular}{|c|l|l|l|l|l|l|}
\hline & 0.17 & 4.79 & 0.17 & 18.42 & 0.17 & 1.45 \\
& 20.00 & 1.58 & 20.00 & 14.47 & 20.00 & 1.31 \\
& 23.50 & 1.58 & 23.50 & 14.83 & 23.50 & 1.24 \\
& 43.50 & 1.46 & 43.50 & 14.83 & 43.50 & 1.24 \\
& & & 67.00 & 16.89 & & \\
& & & 71.00 & 17.88 & & \\
\hline \multirow{5}{*}{$5 \%$ wt. aqueous solution } & & 94.50 & 15.18 & & \\
& 0.17 & 18.99 & 0.17 & 6.39 & 0.17 & 17.37 \\
& 20.00 & 14.14 & 20.00 & 1.67 & 20.00 & 13.51 \\
& 23.50 & 14.47 & 23.50 & 1.73 & 23.50 & 16.43 \\
& 43.50 & 14.14 & 43.50 & 1.67 & 43.50 & 16.88 \\
& 67.00 & 15.99 & & & 67.00 & 20.26 \\
& 71.00 & 18.42 & & & 71.00 & 20.26 \\
& 94.50 & 10.86 & & & 94.50 & 11.69 \\
\hline
\end{tabular}

Table 3. Results of laboratory studies of petrocollecting capacity of octadecyl isopropylolamine with respect to Ramana crude oil thin (thickness $\sim 0.17 \mathrm{~mm}$ ) film; room conditions

\begin{tabular}{|c|c|c|c|c|c|c|}
\hline \multirow{2}{*}{ State of reagent } & \multicolumn{2}{|c|}{ Distilled water } & \multicolumn{2}{|c|}{ Fresh water } & \multicolumn{2}{|c|}{ Sea water } \\
\hline & $\tau$, hour & $\mathrm{k}$ & $\tau$, hour & $\mathrm{K}$ & $\tau$, hour & $\mathrm{K}$ \\
\hline \multirow{7}{*}{ Unthinned reagent } & 0.17 & 16.43 & 0.17 & 7.99 & 0.17 & 11.52 \\
\hline & 21.00 & 25.33 & 21.00 & 23.38 & 21.00 & 21.51 \\
\hline & 24.50 & 33.77 & 24.50 & 26.43 & 24.50 & 23.38 \\
\hline & 44.50 & 35.76 & 44.50 & 26.43 & 44.50 & 21.51 \\
\hline & 68.00 & 24.32 & 68.00 & 22.51 & 68.00 & 18.42 \\
\hline & 72.00 & 24.32 & 72.00 & 22.51 & 72.00 & 18.42 \\
\hline & 95.50 & 5.06 & 95.50 & 11.05 & 95.50 & 9.35 \\
\hline \multirow{6}{*}{$\begin{array}{l}5 \% \text { wt. aqueous } \\
\text { solution }\end{array}$} & 0.17 & 3.25 & 0.17 & 8.35 & 0.17 & 12.25 \\
\hline & 1.50 & 14.47 & 1.50 & 12.52 & 1.50 & 16.25 \\
\hline & 21.00 & 27.83 & 21.00 & 30.14 & 21.00 & 16.25 \\
\hline & 44.50 & 27.83 & 44.50 & 25.84 & 44.50 & 26.79 \\
\hline & 48.50 & 27.83 & 48.50 & 19.04 & 48.50 & 27.83 \\
\hline & 72.00 & 13.15 & 72.00 & 12.47 & 72.00 & 20.67 \\
\hline \multirow{6}{*}{$\begin{array}{l}5 \% \text { wt. ethanolic } \\
\text { solution }\end{array}$} & 0.17 & 13.15 & 0.17 & 24.95 & 0.17 & 12.52 \\
\hline & 1.50 & 7.59 & 1.50 & 28.94 & 1.50 & 12.52 \\
\hline & 21.00 & 12.39 & 21.00 & 36.17 & 21.00 & 16.52 \\
\hline & 44.50 & 30.14 & 44.50 & 31.45 & 44.50 & 19.55 \\
\hline & 48.50 & 31.45 & 48.50 & 31.45 & 48.50 & 20.09 \\
\hline & 72.00 & 11.48 & 72.00 & 20.67 & 72.00 & 9.91 \\
\hline
\end{tabular}

From Table 3 it follows that octadecyl isopropylol amine is an effective petroleumcollecting agent in all waters and in all forms of application. For example, in the sea water, when using $5 \%$ aqueous solution of this surfactant, $\mathrm{k}_{\max }$ has the value 27.83 , the retention time surpassing 3 days.

To compare results shown in Tables 2 and 3 , it may be concluded that the second synthesized surfactant with a longer hydrocarbon group $\left(\mathrm{C}_{18}\right)$ has a higher petrocollecting capacity.

The use of PO propoxylation was also performed with DETA-based aminoamide of monocarboxylic acids fraction of linseed oil. The procedure of obtaining this amino amide is described in [8]. The scheme of the aminoamide propoxylation is as follows: 


$$
\begin{array}{lll}
\mathrm{R}-\mathrm{C}(\mathrm{O}) \mathrm{NH}-\left(\mathrm{CH}_{2}\right)_{2}-\mathrm{NH}-\left(\mathrm{CH}_{2}\right)_{2}-\mathrm{NH}_{2} \stackrel{\mathrm{PO}}{\longrightarrow} & \\
\mathrm{R}-\mathrm{C}(\mathrm{O}) \underset{\mathrm{N}}{\mathrm{N}}\left(-\mathrm{CH}_{2}\right)_{2} & \left.\mathrm{~N}-\mathrm{CH}_{2}\right)_{2} & \text { । } \\
\mathrm{CH}_{2} \mathrm{CH}(\mathrm{OH}) \mathrm{CH}_{3} & \mathrm{CH}_{2}-\mathrm{CH}(\mathrm{OH}) \mathrm{CH}_{3} & \mathrm{CH}_{2} \mathrm{CH}(\mathrm{OH}) \mathrm{CH}_{3}
\end{array}
$$

Propoxylation degree was found to be 4 . confirmed by IR-spectroscopy. The IRThe obtained product is a light-brown viscous liquid. Its structure and composition have been spectrum is presented in Fig.1.

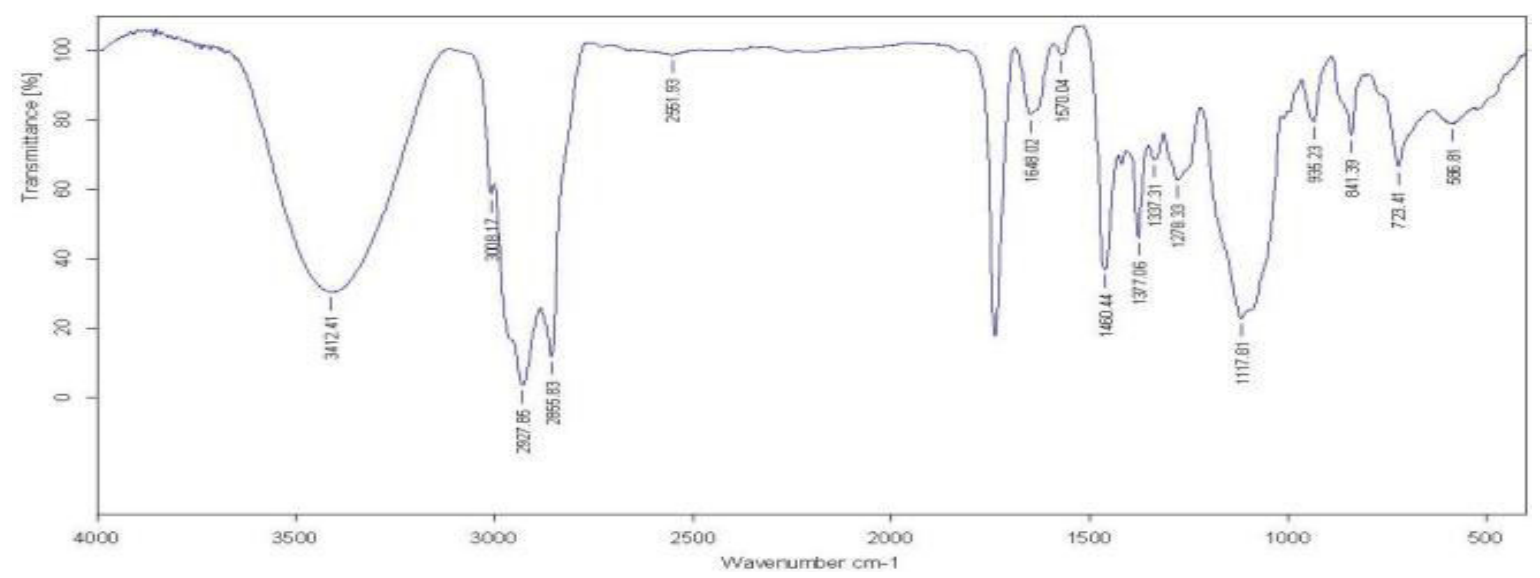

Fig. 1. IR-spectrum propoxylate $(n=4)$ of DETA - based aminoamide of linseed oil acid fraction

In the range $3200-3600 \mathrm{~cm}^{-1} \mathrm{O}-\mathrm{H}$ and $\mathrm{N}-$ $\mathrm{H}$ bonds valent, at $2966 \mathrm{~cm}^{-1}-\mathrm{C}-\mathrm{H}$ (of double bond) valent, 2925 and $2856 \mathrm{~cm}^{-1}-\mathrm{C}-\mathrm{H}$ (of $\left.\mathrm{CH}_{3}\right)$ and $\mathrm{C}-\mathrm{H}\left(\mathrm{CH}_{2}\right)$ valent, $1645 \mathrm{~cm}^{-1}-\mathrm{C}=\mathrm{O}$ valent, $1550 \mathrm{~cm}^{-1}-\mathrm{NH}$ deformational, 1456 , 1416 and $1373 \mathrm{~cm}^{-1}-\mathrm{C}-\mathrm{H}$ (of $\mathrm{CH}_{3}$ and $\mathrm{CH}_{2}$ groups) deformational, 1279 and $1131 \mathrm{~cm}^{-1}-$
$\mathrm{C}-\mathrm{N}$ valent, $1050 \mathrm{~cm}^{-1}-\mathrm{C}-\mathrm{O}$ valent (of $\mathrm{C}-\mathrm{OH}$ group) and $716 \mathrm{~cm}^{-1}-\left(\mathrm{CH}_{2}\right)_{\mathrm{n}}-$ "pendulum" vibrations bands are observed.

The results of surface tension measurements for the synthesized propoxylate at the border air-water are given in Table 4.

Table 4. Results of surface tension measurements for propoxylate $(n=4)$ of DETA-based aminoamide of linseed oil acid fraction at the border air - water at $25^{\circ} \mathrm{C}$

\begin{tabular}{|l|l|l|l|l|l|l|}
\hline \multicolumn{7}{|c|}{ Concentration of the reagent, \% wt } \\
\hline 0.0010 & 0.0025 & 0.0075 & 0.0100 & 0.0250 & 0.0750 & 0.1000 \\
\hline \multicolumn{7}{|c|}{ Surface tension, $\mathrm{mN} / \mathrm{m}$} \\
\hline 29.03 & 29.79 & 29.00 & 28.50 & 28.56 & 28.76 & 28.52 \\
\hline
\end{tabular}

From these results it may be concluded that this propoxylate is surface-active because it lowers surface tension at the indicated border from $\sim 72.0$ down to $28.5 \mathrm{mN} / \mathrm{m}$ (at $0.01 \% \mathrm{wt})$.
The results of laboratory tests of the obtained propoxylate on petrocollecting and petrodispersing capacities are presented in Table 5. 
Table 5. Results of laboratory tests of propoxylate $(n=4)$ of aminoamide of linseed oil acid fraction on petrocollecting an petrodispersing capacities by the example of thin (thickness $\sim 0.17$ $\mathrm{mm}$ ) films of Ramana crude oil; room conditions.

\begin{tabular}{|c|c|c|c|c|c|c|}
\hline \multirow{2}{*}{$\begin{array}{c}\text { State of reagent } \\
\text { at application }\end{array}$} & \multicolumn{2}{|c|}{ Distilled water } & \multicolumn{2}{c|}{ Fresh water } & \multicolumn{2}{c|}{ Sea water } \\
\cline { 2 - 7 } & $\tau$, hour & $\mathrm{k}$ & $\tau$, hour & $\mathrm{k}$ & $\tau$, hour & $\mathrm{k}$ \\
\hline & $0-2.0$ & 5.1 & $0-2.0$ & Disp. & $0-2.0$ & 3.7 \\
Unthinned & $2.0-24.5$ & 13.5 & $2.0-24.5$ & 29.7 & $2.0-24.5$ & 24.3 \\
reagent & $25.0-169.0$ & 30.4 & $25.0-169.0$ & 30.4 & $25.0-169.0$ & 30.4 \\
& $169.0-280.0$ & -40.5 & $169.0-280.0$ & 24.3 & $169.0-280.0$ & 24.3 \\
\hline & $0-2.0$ & 4.7 & $0-2.0$ & 5.1 & $0-2.0$ & 60.8 \\
$5 \%$ wt. aqueous & $2.0-24.5$ & 6.0 & $2.0-24.5$ & Disp. & $2.0-24.5$ & 40.5 \\
solution & & & & $(99.7 \%)$ & & \\
& $25.0-169.0$ & 40.5 & $25.0-169.0$ & 30.4 & $25.0-169.0$ & 20.3 \\
& $169.0-280.0$ & 61.0 & $169.0-280.0$ & 40.5 & $169.0-280.0$ & 30.4 \\
\hline
\end{tabular}

According to the results above, the mentioned propoxylate manifests mainly petrocollecting properties. The values of collecting ratio exceed those for propoxylates of the two alkyl amines as shown above. For example, in fresh and sea waters the value of " $k$ " reaches 40.5 and 60.9 , respectively.

\section{REFERENCES}

1. Lange K.R. Surfactants Sanct-Petersburg: Professiya, 2005, 239 p. (In Russian).

2. Humbatov H.H., Dashdiyev R.A., Asadov Z.H. et al. Nonionic surfactants. Characteristics, obtaining, properties and application. Baku: Elm, 2000. 333 p. (In Azerbaijan).

3. Humbatov H.H., Dashdiyev R.A. Application of surfactants for liquidation of oil spills on the water surface. Baku: Elm, 1998. 210 p. (In Azerbaijan).

4. Schönfeldt N. Surfactants based on ethylene oxide. Moscow: Chemistry, 1982. 752 p. (In Russian).

5. Asadov Z.H. Azerbaijan oil industry. 2009, №2, p. 60-65.
6. Aga-zade A.D. Doctoral dissertation "Obtaining and application of surfaceactive propoxy-derivatives of aliphatic alcohols and higher monocarboxylic acids and compositions based on them". Azerbaijan, Baku: Institute of Petrochemical Processes of Azerbaijan National Academy of Sciences, 2006. 399 p.

7. Trifonova M.Yu., Bondarenko S.V., Tarasevich Yu.I. Ukrainian Chemical Journal, 2009, 75, № 1, p. 28-32.

8. Asadov Z.H., Zarbaliyeva I.A., Eyyubova S.K. Materials of International Conference "Actual problems of modern chemistry and biology". 12-13 May 2016, Ganja State University. Ganja, 2016, p. 43-47 (In Azerbaijan). 


\section{ОКСИПРОПИЛИРОВАНИЕ АЛИФАТИЧЕСКИХ АМИНОВ С ПОМОЩЬЮ ОКСИДА ПРОПИЛЕНА}

\section{З.Г.Асадов, И.А.Зарбалиева, С.Г.Заргарова}

Институт Нефтехимических Прочессов им. акад. Ю.Г.Мамедалиева Национальной АН Азербайджана

AZ 1025 Баку, пр. Ходжаль, 30.e-mail: anipc@dcacs.ab.az

Осуществлено оксипропилирование нониламина, октадециламина и аминоамида фракции карбоновых кислот льняного масла с использованием оксида пропилена. Строение и состав полученных оксипропильных производных подтверждень методом ИКспектроскопии. Тензиометрическими измерениями обнаружена высокая поверхностная активность этих соединений. Лабораторныли испытаниями на примере тонких пленок раманинской нефти на поверхности дистиллированной, пресной и морской вод установлена хорошая нефтесобирательная способность синтезированных реагентов.

Ключевые слова: амины, оксипропилирование, поверхностная активность, нефтесобирательная способность

\section{ALIFATIK AMINLORINN PROPILEN OKSIDİ ILO OKSIPROPILLOŞDİRILMOSI}

\section{Z.H.Osadov, İ.A.Zarbaliyeva, S.H.Zargarova}

AMEA Y.H.Mammadaliyev adına Neft-Kimya Proseslari Institutu AZ 1025 Bakl,Xocall prospekti, 30.e-mail:anipc@dcacs.ab.az

Nonilamin, oktadesilamin vo kətan yă̆ının karbon turşuları fraksiyasının aminoamidinin propilen oksidi ila oksipropillaşdirilmasi həyata keçirilmişdir. Alınmış oksipropil töramalarinin quruluşu vo tarkibi IQ-spektroskopiya üsulu ila tasdiq edilmişdir. Tenziometrik ölçmalarla bu birlaşməlarin yüksək səthi aktivliya malik olması aşkar olunmuşdur. Ramana neftinin distilla, içmali va dəniz suyu səthindəki nazik neft təbəqalari üzarində aparılmış laboratoriya sınaqları naticasində həmin reagentlarin yaxşı neftyı ğıcılıq qabiliyyati müəyyən edilmişdir.

Açar sözlor: aminlar, oksipropillaşdirilma, sathi aktivlik, neftylğma xassalari.

Redaksiyaya daxil olub 05.01.2017. 